\title{
Duns Scotus'ta Tanrı ve Ahlâk Yasası ${ }^{[*]}$
}

\section{God and the Law of Ethics in Duns Scotus}

FATİH ÖZKAN 을

Ankara Hacı Bayram Veli University

Received: 13.II.20I8 | Accepted: 25.03.2019

\begin{abstract}
Scotus is an important figure in the maturation period of medieval Christian theology. In the center of almost all of Scotus's issues, there is also a problem of establishing the relationship between faith and reason, which is the subject of much debate in the Middle Ages. In matters relating to the relationship between reason and will, Scotus's thoughts bear the traces of the Augustinian-Franciscan tradition in many ways. Thus, the moral and religious content of Christianity is more meaningful than the theoretical constructs of belief. Scotus sought to undermine the claim that everything was necessary and unchanging, with a strong theory of logic. In this context, he made a brilliant discovery which he conceptualized as 'simultaneous contingency'. The essence of this contingency theory, which deeply influences the classical Christian conception of Scotus, is based on the understanding that actual reality can be different from what actually is. The theory of contingent reality, in a sense, refers to the liberation of Christian thought from the ancient Greek thought. The essence of the theory of contingency of Scotus is the fact that opposites are possible at the same time. The systematic thought of Scotus is based on the main methodological distinction between the theology of necessity and the theology of contingency. In addition to the compulsory propositions, the knowledge of contingent propositions depends on this doctrine. In addition to the compulsory propositions, the knowledge of contingent propositions depends on this doctrine. In fact, contingent propositions constitute the largest part of theology.
\end{abstract}

Keywords: Duns Scotus, God, will, moral law, synchronic contingency.

(C) Özkan, F. (2019). Duns Scotus'ta Tanrı ve Ahlâk Yasası. Beytulhikme An International Fournal of Philosophy, 9 (I), I8I-2IO.

$\triangle$ Fatih Özkan

AHBVÜ, Polatlı İlahiyat Fakültesi, Felsefe ve Din Bilimleri Bölümü 0690o, Ankara, Turkey | fozkantr@hotmail.com 


\section{Giriș}

Ortaçağ Batı Felsefesi teoloji ve metafizik olmak üzere iki ayrı sistemin mücadelesine sahne olmuștur. Diğer bir deyișle, vahyin Tanrı'sı ile felsefenin Tanrı'sı karșı karșıya gelmiș ve Hristiyan teolojisi bununla yüzleșmek durumunda kalmıștır. Ortaçağ Hristiyan teolojisinin olgunlașma döneminin önemli șahsiyetlerinden biri olan Duns Scotus da felsefenin etkin olduğu bu kültür ortamında yașamıș ve Tanrının zatı, sıfatları, varl1ğının kanıtlanması, evrenle ilișkisi gibi pek çok konunun incelenmesinde haklı bir șöhretin sahibi olmuștur.

Scotus'un ele aldığı konuların hemen hepsinin merkezinde, aynı zamanda Ortaçağın en çok tartıșma konusu olan iman ve akıl arasındaki ilișkinin tesis edilmesi problemi yer alır. Ortaçă̆ insanın her ikisine de muhtaç oldukları görüldüğü için Ortaçă̆ dünya görüşü, ikisinin de baștan sona uyumunun tesis edilmesi gayretlerini ortaya çıkarmıștır. Bundan hareketle Scotus'un, Hristiyan imanının akılsallığını kanıtlamayı, bir nevi kendisinden önce St. Thomas'ın denediği șeyi daha güçlü kılmayı hedeflemiș olduğunu söyleyebiliriz (Jones, 2006: 492). O, bir taraftan evrenin yaradılıșı, ruhun ölümsüzlüğü, Meryem'in masumiyeti gibi konularda inayetçi bir tavır takınırken, diğer taraftan da iyi bir matematik eğitimi almasının da etkisiyle, bir delili kabul ederken seleflerinden daha titiz bir üslup benimsemiștir (Vorlander, 2004: 29I).

Akıl ve iradenin ilișkisine dair konularda Scotus'un düșünceleri birçok yönden Augustinuscu-Fransisken geleneğin izlerini tașır. O iradenin akılla ilișkisinde, gerçekte sevginin bilgiye karșı üstünlüğünü ileri sürmektedir. Buradaki üstünlük, Tanrı'nın mevcudatın bütününden daha çok sevilmesi gerektiğini esas alan en yüksek pratik ilkeyle yakından ilgilidir (Copleston, I954: 205).

Skolastik dönemde Thomasçı felsefe büyük Dominiken tarikatinin resmi öğretisi olmuș ve birçok yandaș kazanmıș olsa da tartıșmasız bir üstünlüğe sahip değildi. İlk büyük öğretmenleri Hales'li Alexander ve Bonaventura olan Fransisken okulları Aristotalesçiliği yadsımasalar da, kendi Augustinusçu-Platoncu geleneklerini izlediler. Fransiskenler dinin kılgısal, duygusal, gizemsel, kișisel ve tapınmaya yönelik yanını vurguladılar; onlar için akıl iradeden daha az önemliydi. Hıristiyanlığın 
ahlâkî ve dinî içeriği, onlar için inancın kuramsal yapılandırmalarından daha anlamlıydı. Yeni skolastisizmin birçok eleștirmeni ve karșıtının bu düzenden çıkması doğaldı (Thilly, 2000: 205).

Ortaçağ düșünce dünyasında, Scotus da dâhil olmak üzere fransiskenlerin izleyebileceği birkaç olanaklı yön bulunmaktaydı: ilki, başat felsefenin belli ilkelerine karșı çıkmak; ikincisi, Hıristiyanlık ile Arist otelesçiliğin örtüştürülmesini başarısız görüp reddetmek; üçüncüsü, inancın ispatlanabilirliğini yadsımak; dördüncüsü, skolastizmin olanağını toptan yadsımak. Bu konumlardan ilk üçünü benimseyerek Duns Scotus dördüncüsünün kabulüne giden yolu hazırlamıș ve böylelikle skolastik dizgenin yıkılmasına katkı sağlamıștır da denilebilir (Thilly, 2000: 206).

Weber, Skolâstik dönemde tarikatlerin düșünürler üzerindeki etkisini konu ederken șu saptamada bulunmuștur: "St. Thomas, tarikatının tamamıla dogmatik ve öğretici olan misyonuna sadık kalmıștır. Aynı șekilde tarikatının canlı ve pratik dindarlık ruhunu almıș olan Duns Scotus, inancın amelî tezahürlerinin ve insan özgürlügüünün öncüsü olmuș ve bu zaviyeden Thomas'ın görüșlerinin eleștirisine yönelmiștir."(Weber, I998: 174).

Scotus'un felsefi düșüncelerinin șekillendiği ortamın incelenmesi bizim onun felsefesine nüfuz etmemizi kolaylaștırır. Zira St. Thomas felsefesi son devir Ortaçağ felsefesi için olduğu kadar Scotus için de ister istemez önemli bir evreyi olușturur. Çünkü St. Thomas'ın Orta Çağ düșüncesiyle bağıntısı Platon ve Aristoteles'in klasik düșünceyle olan bağıntısıyla ana hatlarıyla eșdeğerdir. Ancak klasik düșünce ile Orta Çağ düșüncesinin kapanıs, dönemleri arasında ciddi bir fark göze çarpmaktadır. Şöyle ki "klasik düșüncenin son dönemi, baskın kavramsal șemanın çerçevesi içinde gelișmekte özgürdü. $\mathrm{O}$ șema entelektüel uygunluk duygusundan bașka herhangi bir șey tarafından kısıtlanmamıștı. Dolayısıyla kendisini, șehirdevletten imparatorluk modeline doğru gerçekleșen büyük değișime ve olup biten öteki kültürel değișimlere ayarlaması mümkündü. Fakat ortaçağlar felsefî doruk noktasına varır varmaz, yeni kavramsal șema katı bir ortodoksi içerisinde kemikleșmiș bir hal almıștır. Böylelikle egemen sistem içinde herhangi bir büyük değișim imkânsızlaștığından, felsefi düșünce Ortaçağ dünya görüșünün dıșında gelișmiștir.” (Jones, 2006: 450). 
Bu durumda Ortaçă̆ felsefesi için bir yol ayrımı mukadder hale geldi. "Bir yandan Thomascılık Kilisenin resmi felsefesi haline geldiği için, fiilen değișikliğe uğramadan günümüze kadar varlığını korudu. Diğer taraftan, 'özgür' diye adlandırılabilecek düșüncenin bakıș açısından Thomascılık bir anda saldırı altında kaldı ve daha üç yüzyıl dolmadan büyük ölçüde çökertilip terk edildi. Bir felsefenin bir ve aynı zamanda kimileri için her șey, kimileri içinse hiçbir şey olabilmesi modern zamanların parçalanmıșlı̆̆ının bir alametidir.” (Jones, 2006: 45I). Ortaçağ'da bu ayrıșmanın zeminini, teolojik hakikatle akılsal hakikati birbirinden ayıran ve bunların birbirine kavușmalarının mümkün olmadığını savunan İbn Rüșdçülerin çifte hakikat öğretisine götüren bir yaklașım teșkil ediyordu (Jones, 2006: 97). Buna göre akıl ve vahiy alanları birbirinden ayrı iseler, aklın ilahi yardımlara bașvurmaksızın ișleyebilemesi ve kendine özgü hakikat türüne kendine özgü yollarla ulașabilmesi mümkün olmaktadır.

Scotus'un Orta Çağ düșüncesindeki konumu șöyle özetlenebilir: Kabul edilmiș metafiziksel ilkelerin uygulamasına ilișkin eleștiricilik ile metafiziksel sistemlerin temellerine ilișkin eleștiriciliği birbirinden ayırdığımızda, bunlardan ilki, Ortaçağın büyük spekülatif düșünürlerinin bütünü tarafından uygulanmıștır. Ancak I4. y.y.'a kadar ikincisinin uygulanmasına pek rastlanmaz. Scotus düșüncesi bu anlamda bir ilk olma hüviyeti tașır (Copleston, I954: 565-6). Onun düșünceleri, esasında seleflerinin düșüncelerine görünüște olduğundan daha az bağlıydı. Onun Hristiyan düșünceyi özümsemek veya eleștirmek amacryla, yeniden ve kendi hesabına Aristoteles'ten, Proclus'tan, Ibn Sina'dan ve Ibn Rüșt'ten yola çıktığını unutmamak gerekir (Gilson, 2007: 574).

Çalıșmamızın konusuyla ilișkilendirmek açısından Scotus'un iradeci yaklașımlarının temellerini irdelemekte fayda vardır. Onun konuya ilișkin görüșlerinin özellikle Augustinus düșüncesinde belirgin iz düșümleri göze çarpar. Augustinus, Scotus'un düșüncelerinin șekillenmesinde önemli kilometre tașlarından birini olușturur. Hatırlanacağı üzere o, Tanrı'nın iradesinin kayıt altına alınmasına karșı çıkar. İtiraflarım' da bu yaklașımını șöyle dile getirir: "Sen ne yerde ne de gökte gördüklerimize benzersin ne de gözümüzden kaçanlara. Çünkü onları sen yarattın. Yaratabileceğin en harika yapıtlar, bunlardan ibaret değildir." (Augustinus, I999: 58). Augus- 
tinus, görüșlerine İncil'den bazı ayetleri dayanak yaptığını görmekteyiz. Zira İncil'de, "Tanrım sen insanın bașındaki saçların sayısını biliyorsun, bir tek saç teli bile senin iraden dıșında düșmüyor.”(Mat. ıo, 30) buyrulmaktadir (Augustinus, ı999: 85).

Scotus kendinden önceki Skolastiklerden, özellikle de aklın irade üzerindeki önceliği ve üstünlüğü üzerinde ssrar eden Aquinalı Thomas'tan, esas itibariyle iradenin akıl karșısındaki önceliği ve üstünlüğünde ısrarlı olmak bakımından farklılık gösterir. İradenin insanda aklı hareket geçirdiği veya yönettiği, örneğin insanların belli șekillerde düșünmeyi istemeleri olgusuyla ilișkilendiren Duns Scotus, iradenin bir nesneye ilișkin bilginin gerçek nedeni olduğunu savunmuștur. Aklın kendisinden bașka nedenleri vardır, oysa iradenin nedeni bir bütün olarak irade etmeden bașka hiçbir șey değildir (Dekker, ı998: I15-6).

A. Weber, zihnin irade üzerindeki üstünlügüünü kabul eden Thomascı determinizmin, kilise çevrelerinde kabul görmesinin nedeni olarak, bu felsefenin kilisenin otoritesini tahkim ettiğini ileri sürer. Ona göre, bu felsefe, iradeyi mutlak bir prensibin boyunduruğu altında eğerek, bireyin gururunu ezer, kendi güçlerine olan güvenini yıkar. Oysa bu anlayıs,, gerçekte, bir taraftan bizzat Tanrı'yı, iradesi zekânın esiri olan bağımlı bir varlık yapmakta; diğer taraftan ise, bireyi așağılamaktan daha fazlasını yapıyor: onun cesaretini kırıyor, onu ümitsizliğe yahut ahlâkî ilgisizliğe düșürüyor (Weber, I998: 174).

Ortaçağ'da tartışma konusu olan zihnin veya iradenin önceliği veya üstünlüğü sorunu günümüzde doğa zorunluluk ve irade özgürlüğü arasındaki anlașmazlık șeklinde varlığını sürdürmektedir (Vorlander, 2004: 292). Scotus'a göre 'Akıl, karșısında irade, öncelik ve üstünlüğe sahiptir. (Voluntas est superior intellectu). İrade, ruhun asli gücüdür. Thomas'ın kabul ettiği gibi, Scotus'a göre de 'ilk akletme', ruh ile dıșsal eșyanın birleșen faaliyetiyle, yani dıș Dünyanın izlenimleriyle meydana gelir. İște bu ilk akletme, 'belirsiz ve kapalı'dır. Onun belirli ve açık bir biçim alması, ancak iradenin dikkatini bu kapalı tasavvurlar üzerine yöneltmesi, ona kesinlik kazandırması ve șiddetini artırması sayesinde gerçekleșir. Aksi halde eșyanın izlenimi zayıflar ve kaybolur. Ona göre tasavvur faaliyeti iradenin, ancak hizmetçisi ve rastlantısal bir nedenidir. Karar vermek iradeye düșer. İrade psikolojisinde Orta Çă̆’ı bu incelikli bilgini, daha o zamandan 
sayısız ince gözlemleri ve ince bir düșüncenin eseri olan ayırımlar (örneğin istemekle eğilim duymak arasında bir ayırım) yapmaktadır (Vorlander, 2004: 292).

Scotus, her șeyin zorunlu ve değișmez olduğunu iddiasını mantık örgüsü güçlü olan bir teoriyle çürütme yoluna gitmiștir. Bu bağlamda "eșzamanlı olumsallık" diye adlandırdığı parlak bir keșifte bulunmuștur. Lectura I 39, ${ }^{\mathrm{I}}$ bu keșfin bir açıklamasıdır. Scotus'un klasik Hristiyan anlayıșını derinden etkileyen bu olumsallık teorisinin esası, fiili gerçekliğin gerçekte olandan farklı da olabilmesine dayanır. Tanrı, temelde özgürdür; bundan ötürü yaratma ve yeniden yaratmakta özgürdür. Mevcudat, olduğundan bașka türlü de olabilirdi (Scotus, I994: 6). Bu anlayıș, evrenimizin doğas1nın ve tarihinin anlașılmasında bizi belirli bir sonuca götürmektedir. Scotus, bu noktada "Tanrı'nın iradesi nasıl olumsallığın nedeni sayılabilir?” sorusunu gündemine tașımaktadır. Ona göre Tanrısal irade zıt etkiler üretmekte özgürdür. Tanrısal irade yalnızca bir seçimde bulunabilir. Bu nedenle tek bir seçimi zıt objelerin her birinden yana kullanabilir. Tanrı'nın sınırsız seçimi zıt objelerle ilgilidir. Tanrısal özgürlük bir ve aynı seçimden dolayı zıt objelerle ilișkilendirilebilir ve bizim seçimlerimizden daha özgürdür (Scotus, I994: 124).

Lectura I 39'daki Scotus'un teorisinin ana hatları, onun antropolojisi ve Tanrı öğretisinin bașka öğeleri için bir çerçeve sağlamıștır. Lectura I 39'da Scotus, Tanrı'nın bilgisi ile șeylerin olumsallığının gerçekte birbiriyle uyumlu olduğunu iddia etmektedir; Tanrı'nın bilgisi, belirlenimli, yanılmaz, değișmez olmakla birlikte zorunlu değildir. Özetle Lecture I 39'daki ana hedefin antik zorunlulukçulukla yüzleșmek olduğunu söyleyebiliriz. Scotus'un bu yüzleșmeci tavrının ardında her șeyden önce eleștirel kișiliği yer almaktadır. Onun felsefesinin ayırt edici özelliği, başka düşünce sistemlerinin, özellikle de Thomas Aquinas'ın düșünce sisteminin eleștirisidir. Pek çok noktada Kilise, Scotus'un felsefesine karșı Thomas'ınkini

\footnotetext{
I Lectura I 39, Duns Scotus'un Opus Oxoniense adlı eserinden bir bölüm. Aynı zamanda müstakil bir kitap olarak da basılmıștır (Scotus, 1994). Opus Oxoniense ve dolayısıyla Lectura, Peter Lombard'ın Sentences adlı eserinin Duns Scotus tarafından yapılmış olan bir șerhidir. Scotus, bu șerhi Oxford'da genç bir teologken yapmıștır. Lectura I 39 ise, felsefe ve teoloji tarihinde ilk kez Duns Scotus tarafindan ortaya atılan ve Scotus yorumcusu A. Vas'in İngilizce'de "synchronic contingency" (eșzamanlı olumsallık) olarak karșıladığı mantıksal ve ontolojik teorinin geniș bir açılımını vermektedir. Bu teori Scotus teolojisinin önemli bir özelliğini olușturur. Vos, 2000: 9.
} 
yeğlemiștir. ${ }^{2}$ Yine Thomas'a azizlik unvanı verirken, Scotus'a vermemiștir. $^{3}$

Bir fransisken rahibi olarak Scotus'un yașadığg dönemde fransiskenlerin genel izlenimi șöyleydi: İnsan, tabiatın bütününe bir sevgi bağı ile sıkı sıkıya bağlıdır. Buna göre Tanrı'nın bizzat kendisiyle ve teslisteki üç șahsiyetin birbiriyle olan ilișkisinde bir sevgi bağından söz edilebilir. Bu sevgi, ilahi sevgiden doğmaktadır. Dünya, Tanrı tarafından sevgi aktı ile yaratılmıș ve varlığını bu sayede devam ettirmektedir. Ortaçağlarda sevgi saikiyle ilahi olana benzeme methedilmiștir. Fransisken düșünce sisteminde sevgi, evrenin merkezindedir. Bu düșünce Scotus'un çocukluk dönemi eğitiminin ana eksenini olușturmuștur. $\mathrm{O}$, felsefesinde sevgi ve irade arasındaki sıkı münasebete vurgu yapar ve iradenin, sevginin yer aldığı alanda güç kazandığını iddia eder. İrade, sevginin alanında yer alır. Scotus, teolojik düșüncelerinde Tanrı'nın aklından ziyade iradesine odaklanır. Onun Tanrı'nın iradesine ilișkin öğretisi, özellikle de Tanrısal iradenin sonsuzluğuna vurgu yapması, doğal (natural) teolojinin bütününe teșmil edilebilecek ehemmiyette bir anlatımı içerir. Onun irade doktriniyle ilgili akl1mızda bulundurmamız gereken husus șudur: özgür irade zıt etkiler üretebilir; pek çok koșulda ürettiği etkinin yerine eșit derecede zıt bir etki de üretebilir (Broadie, I995).

2 Roma Katolik kilisesinin, Scotus'un Meryem'in Masumiyeti öğretisini kabul etmesi, bunun bir tek istisnası sayılabilir. Bkz. Wolter \& O’Neill, 1993.

3 Papa XVI. Benedict'in 2006 yılında Almanya gezisi sırasında Regenburg Üniversitesinde 'akıl ve inanç' bağlamında yaptığı konușmada, İslam'la birlikte eleștiri oklarının yöneltildiği taraflardan birinin de Duns Scotus olması anlamlıdır. Papa, genelde Latinleri, özelde ise Scotus'u hedef aldığı konușmasında șu sözlere yer vermiștir: "Doğrusu, Ortaçağların sonunda, ilahiyatta, Hristiyan ruhu ile bu ruha iştirak ettirilmiș olan Grek ruhu arasındaki sentezi parçalayacak eğilimler görmekteyiz. Duns Scotus, iși, Tanrı'nın kelamından bağımsız olduğunu, onun bize hakikati açıklamak gibi bir zorunluluğu dahi olmadığını (söyleyecek kadar ileri götürmüș)... ve eğer o irade buyurmuş olsaydı, insan putperestliğe de tabi olmak zorundaydı (görüșüne kadar vardırmıștır)." Çünkü Papa'ya göre, böyle bir Tanrı anlayışında, "Tanrı'nın așkınlığı ve ötekiliği (otherness), o kadar yüceltilir ki, artık aklımız, hakikate ve iyiye dair duygumuz, en derin imkanları ezeli olarak ulaşılamaz olarak kalan ve fiili kararlarımızın arkasında gizli olan Tanrı'nın sahici bir aksini bulamayız." Oysa, "Kilise'nin inancı, Tanrı ile bizim aramızda, Tanrı'nın sonsuz yaratıcı ruhu ile yaratılmıș aklımız arasında gerçek bir benzerlik olduğunda hep ısrarcı olmuștur.” İnancın rasyonelliğine kușkuyla yaklașan düșünce akımlarına karșı uyarılarda bulunan Papa konușmasını, İmparator II. Mihail Paleologos'un "Akla göre hareket etmemek, Tanrı'nın doğasına zittır.” sözleriyle bağlamıștır. $\quad$ https://w2.vatican.va/content/benedictxvi/en/speeches/2006/september/documents/hf_ben-xvi_spe_200609I2_university-

regensburg.html. 
Scotus, ortaya attığ1 teorileri desteklemek üzere sık sık Aristoteles'in otoritesine başvursa da temelde bir 'Aristoteles takipçisi' sayılamaz. Hatta Scotus'un felsefi eğiliminin Aristoteles'inkinden farklı olduğu açıklıkla ifade edilebilir. Zira ona göre ilk hareket ettirici olarak nitelendirilen Tanrı, bütün sınırlı varlıkların kendisine bağlı bulunduğu, fiziki dünyanın ötesinde sınırsız ve așkın bir varlığı ifade etmekle tanrısal yetkinliği yeterince yansıtmaktan geri kalır. Yine Aristotelesci ahlâk da Scotuscu ahlâk doktrini açısından yetersizdir. Bir ahlâk felsefesi olarak Scotusculuk, Aristotelesçiliğe bağlı ve ona borçlu bir sistem olmaktan uzaktır (Copleston, I954: 485). Bununla birlikte, Scotus'un ahlâk yasasını bütünüyle ilâhî iradenin keyfi seçimine bağladığını söylemek de doğru değildir. Örneğin on emrin ikinci kısmındaki hükümler, onun ahlâkî zorunluluk doktrini açısından doğal yasa kapsamında ele alınabilir. Scotus, bunları ahlâkî zorunluluk yerine ilâhî muafiyet kapsamında değerlendirmektedir (Copleston, I954: 485).

\section{Özgürlük ve Zorunluluk Bağlamında Tanrı'nın İradesi}

Olumsal gerçeklik teorisi, bir nevi Hıristiyan düşüncenin antik yunan düșüncesinden kurtulmasını ifade etmektedir. Buna dayanarak Scotus, ilk olarak olumsal gerçekliğin tutarlı bir ontolojisini sunmaya çalıșmaktadır. İkinci olarak da bilgi ve zorunluluğu sıkıca birbirine bağlayan mutlak bilgi idealinin tesis ettiği bağı ortadan kaldırmaktadır. Daha önce de belirtildiği üzere, Lectura I 39 onun olumsal gerçeklik teorisinin ana hatlarını görmemiz için bize bir çerçeve sunar.

Scotus'a göre, sorulması gereken temel soru, “Tanrı gelecekte olacakların bilgisine her halükarda sahip midir?” biçimindeki varsayımsal ifade yerine, “Gelecek olumsal ile bu olumsallığın Tanrı'nın bilgisi ile uygunluğu var mıdır?" olmalıdır (Scotus, ı994: I9). Zira onun ana hedefi Antikçağ zorunlulukçuluğu geçersiz kılmaktır. Scotus'a göre gerçek olumsallık, bir șeyin zıddının da aynı zamanda mümkün olmasıdır. Scotus'un olumsallık teorisinde değișkenlik ve olumsallıkta olduğu gibi değișmezlik ve zorunluluk da birbirinden ayrı kavramları ifade eder. Buna göre olayların değișmezlik durumu olumsal olabildiği gibi olayların zorunluk tașımaması da Tanrı'nın bilgisinin olumsal gerçekliğini ifade eder. Tanrı olumsal geleceği değiștirmez fakat zorunluluk-dıșı olarak bilir (Scotus, I994: 25-6). 
Tanrı öğretisi açısından bunun anlamı șudur: Biz olumsal aktların ve arizi niteliklerin Tanrı'dan olduğunu düșünebiliriz. Öğretinin özü Tanrı'nın zorunlu varlığını ve bununla ilintili olan zorunlu niteliklerini içine aldığı gibi olumsal aktların büyük çeșitliliği ve arizî nitelikler de onun zenginliğinin kapsamı içine girer. Örneğin Tanrı'nın iyiliği ve adaleti, herșeyi bilmesi gibi onun zorunlu niteliklerindendir. Bununla birlikte Tanrı'nın bizim olumsal geleceğimizin değișmez bilgisine sahip olması onun arizî niteliklerinden biridir (Scotus, I994: 27). Bu arizî nitelikler Tanrı'nın geniș yelpazedeki olumsal yaratmasıyla ilgisini anlamamıza yardim eder.

Scotus'un olumsallık teorisinin özünü zıtların aynı anda mümkün olması olușturur (Scotus, I994: I33). O, olumsallık teorisine ilișkin kendisine yöneltile itirazlara karșı ilk olarak birleșik ve ayrık düșünceler arasında ustalıklı bir ayrıma gider. Bu yaklașımını izah etmek üzere bir örnek verir: S,ayet bir insan hareket ediyorsa anlama yeteneği olan bir varliğın hareket etmesi zorunludur. Birleșik anlamda bu önerme insanla anlama yeteneği olan bir varlık arasında zorunlu bir ilișki bulunmasından dolayı doğrudur. Buradaki ilișkide örtük bir zorunluluk vardır. Ancak bu önerme ayrık anlamda yanlıștır. Buna göre buradaki zorunluluk önermenin yalnızca bir kısmını ihata etmektedir. Bu nedenle "Düș̈̈nme yeteneğine sabip bir varlğ̆ın hareket etmesi zorunludur.” önermesi, düșünme yeteneğine sahip bir varlığın hareket etmesinin zorunlu olmaması nedeniyle yanlıștır (Scotus, I994: I35). ${ }^{4}$

Scotus söz konusu olumsallık yaklașımını Aristoteles'in zorunluluk tezine uygular. Șayet birleșik anlamda okursak bu tez doğrudur ve örtük bir zorunluluk vardır. Zira bir șey varsa o șeyin varliğg zorunludur. Ancak bu ayrık anlamda okunduğunda: Bir șey varsa o takdirde o șey zorunludur. $\mathrm{Bu}$ önerme yaratılmıș olan bir șeyin olumsal olduğu ve bu nedenle zorunlu olarak tanımlanamayacağı için yanlıștır. Scotus burada Aristoteles'in tezinden hareketle zamansal bir ilișkilendirmeye gitmektedir. Ona göre p'nin t'deki zamansal sırası zorunluluğun modal bir ifadesi değildir. Buna göre șayet p olumsal ise bu takdirde t zamandaki p'de aynı șekilde olumsaldır. Scotus'un olumsallı tezinde irade bir șeyi belli bir anda irade etmenin yanı sıra etmeyedebilir. Scotus burada kendisini zor durumda bira-

4 Scotus, birleșik ve ayrık düșünceler arasında, koșulsuz (categorical) ve koșullu (hypothetical) bir önerme arasındaki farktan yararlanarak daha ileri bir açıklamada bulunmaktadır. 
kan Aristoteles'in zorunlulukçu tezine ilișkin değerlendirmesi șöyledir: "Aristotelesçi tez örtük bir doğruluk değeri taşısa da bu eșzamanlı olumsallık teorisini bertaraf edemez." (Scotus, I994: I35). Scotus kendisine yöneltilen diğer bir itirazın cevabında kuvve halindeki iradenin bilfiil iradeye karșı zamansal önceliğini reddeder. O burada a'yı irade etme ve a’yı irade etmeme gücü arasındaki bir ayırımı kastetmez. Onun kastettiği gücün bilfiil iradeden önce gelmesidir. Bir imkân tabiatıyla veya yapısal olarak aynı anda zıddının bilfiil gerçekleșmesine takaddüm eder. Aksi halde her bir olumsal aktta aynı anda kendisinin zıddı bir imkân veya güç varsayılmadığı gibi aynı anda iki zıt aktın çakıșması da varsayılmaz (Scotus, 1994: 139).

Burada Scotus'un eșzamanlı olumsallıkla nedenin yapısal önceliği arasında nasıl bir ilișki kurduğunu görmekteyiz. Buna göre bir neden aktı olumsal ise bu gerçekleștiği anda tabiatıyla olumsaldır. Bu sonuçla Scotus önemli bir noktaya ulaşmaktadır. O belli bir anda olumsallığın nasıl var olabileceğini göstermektedir: Șayet hususi bir anda olumsallık bulunmuyorsa hiçbir zaman bulunmuyor demektir. Ancak bir anda olumsallık bulunursa geçmiș, șimdi ve gelecek olmak üzere her anda bulunur. Dolay1sıyla Tanrı'nın nasıl șeylerdeki olumsallığın nedeni olduğu açıklık kazanmaktadır. Ona göre bu olumsallığın nedeni Tanrı'nın iradesidir (Scotus, I994: I40). Olayların bu șekilde gerçekleșmesi veya başka türlü gerçekleșmemesi Tanrı'nın özgür iradesi nedeniyledir.

Scotus'a göre olumsal șeyler zorunlu kanıtlamalardan çıkarılamaz. Çünkü bir șeyin zorunlu olması, olumsal olmaması demektir. Nasıl ki sıcak niçin sıcaktır, sorusunun tek cevabı sıcak olduğu için ise Tanrı'nın mümkün bir șeyi niçin irade ettiğinin tek cevabı ise onu irade ettiği içindir. Scotus Tanrı'nın kendinde bir gayeye dönük olarak eylemde bulunduğunu onun en yüksek rasyonellikte irade etmesi nedeniyle inkâr etmez. Ancak zorunlu olmayan bir șey için zorunlu bir neden aramanın saçmal1ğını açıkça göstermek ister. Zorunlu bir ilke mümkün bir șeyi takip etmez. Tanrı'nın özgür seçimi mümkün șeylerin nihai nedenidir (copleston, I954: 53I-2).

Scotus'un sorularla yapılandırdığ 1 God and Creatures adlı eserinde tartıșma konusu yaptığı sorulardan biri de șudur: İradenin özgürlüğü ve doğal zorunluluk aynı akt ve nesneyle ilgili olarak birbiriyle uyumlu mudur? 
Görüldüğü üzere bașından itibaren özgürlükle zorunluluk birbirine karșit olarak konumlandırılmıștır. Konuya ilișkin olarak Scotus, Augustinus'a ait șu ifadelere yer verir: "Kanaatimize göre akıl yalnızca irade tarafından arzulanan günahların bir kölesidir.” Sözlerinin devamında Augustinus șunları dile getirir: "Șayet bu eylem kusur addedilecekse bu takdirde tabii değil, iradidir. Bu tașın așağı yönde hareketini andırmaktadır. Bu nedenle hareket bir yönüyle bir kișiye aitken diğer yönüyle de tașa aittir. Ancak tașın așağıya düșerken kendini kontrol etme gücü bulunmamaktadır. Bu nedenle tașın hareketi tabiatı tarafından belirlenirken kișinin hareketi ise iradesi tarafindan tayin edilir.” (Scotus, I975: 369). Dolayısıyla Augustinus'a göre bir iradî hareket farklı yönlere doğru çevrilebilecekse bu takdirde iradi sayılamaz ve aynı nesneye dönük aynı hareket hem özgür hem de doğal olamaz.

Augustinus, Tanrı Devleti'nde görüșlerini șöyle bir delille desteklemektedir: "Șayet zorunlulukla kastettiğimiz șey gücümüzün ötesi ise ve bu, ölümün zorunluluğu gibi irademizin aksini ifade ediyorsa bizim iyilik veya hastalığa ilișkin kanaatlerimiz bu tarz bir zorunluluğun konusu değildir. (...) Öte yandan zorunluluğu, 'șu șöyledir, bu böyledir' tarzında ele alacak olursak bu tarz bir zorunluluk, irade özgülüğümüzü elimizden alır diye korkmamıza gerek yoktur. Herhangi bir zorunlulukla Tanrı'nın ebedi bir hayatta yașadığını ve her șeyi bildiğini söylediğimde Tanrı'nın hayatını ve her șeye ilișkin ön bilgisini tayin etmiș olmuyoruz.” Bu görüșe dayanarak Scotus, kanaatini șöyle sürdürür: "Seçtiğimiz her șeyde özgür olarak seçimde bulunmamız gerektiği doğrudur. Çünkü özgür seçimle özgürlügümüzü ortadan kaldıran bir zorunluluktan bahsetmiș olmayı.”Scotus, Augustinus'un düșüncelerinden hareketle üç hususa dikkat çeker: I. İradenin herhangi bir aktında zorunluluk var mıdır? 2. İradede ilave bir özgürlük var mıdır? 3. Doğal zorunluluk zaman zaman özgürlükle birlikte bulunabilir mi? Scotus'a göre herhangi bir irade aktında zorunluluk vardır. Tanrisal iradenin kendi kendini sevmesi ve kutsal ruha can vermesi aktları yalın anlamıyla zorunludur. Yine açıktır ki Tanrı zorunlu olarak mutludur. Bu nedenle güzel nesneleri zorunlu olarak farkeder ve sever. Aynı șekilde Kutsal Ruh da Tanrı'dır ve bu nedenle Tanrı mükemmel ve zorunludur. O varlığını Tanrı ve Oğlu'ndan aldığı için onlardan kaynaklanan aktların da zorunluluğunu en üst derecede haizdir (Scotus, I975: 370). 
Scotus'un sistemine yöneltilen "Tanrısal irade aktlarının keyfi bir tarzda ișlediği” yönündeki iddialar sağlam bir temelden yoksundur. Zira Tanrı'nın ebedi olarak irade ettiği șeyin zorunlu olarak var olması gerekmez. İrade fiili sonsuzdadır; var olușun meydana gelmesi ise zamandadır. Mantıksal olarak bilme, irade etmeden önce gelse bile Tanrı en yüksek rasyonellikte irade eder. Tanrısal irade irade ettiği için irade eder ve bunun için bir nedene gereksinim duymaz. Tanrı'daki insan tabiatı idesi zorunludur. Ancak Tanrı'nın insan tabiatını niçin bu șekilde tasarladı̆̆ı, ferdi olarak burada ve bu zamanda oluşu Scotus için cevabı verilemeyecek olan sorulardandir (Copleston, I954: 530-I).

Gilson, Scotusçu ve İbn Sinacı imkan teorileri arasında șu tarz bir paralellik görür: Scotusçulukta sonsuz varlı̆̆ın zorunlu var olușu ile sonlu varlığın mümkün var olușu arasındaki köprüde Tanrı'nın iradesinin araya girdiği ontolojik bir boșluk vardır. İbn Sînâ'nın evren anlayıșında ise ilk varlığın zorunlu olması nedeniyle geriye kalanların tümü șartlı zorunludur. Duns Scotus'un evreninde ise ilk varlı̆̆ın zorunlu olması nedeniyle geriye kalanların tümü mümkün statüsündedir. Her ikisi için de zorunlu ve mümkün arasında akla gelen tek bağlantı bir iradenin varlığıdır (Gilson, I978: 460).

Sınırsız irade, mümkün olan en mükemmel nesne ile ilintilidir. Tanrısal irade sınırsızdır. Bu nedenle iradenin kendisiyle ilintili olabileceği en büyük mükemmellik, mükemmel derecede sevilen obje ile ilgilidir. Fakat bu, ilahi irade bu objeyi zorunlu ve yeterli ölçüde sevmedikçe ve bu objeye yeteri kadar sevgi vermedikçe mümkün olmaz. Bu koșullardan biri olușmamıșsa bazen irade daha mükemmel durumdaki bir nesneyle ilgili olduğunda bir karșıtlığın bulunmadığı düșünülebilir. Sınırsız irade, sınırsız bir akte sahip olduğunda kendisiyle çatıșmaz. Bu nedenle zorunlu akt, zorunlu olarak zorunlu nesne ile ilgili bir șekilde ortaya çıkar. Bundan yoksun olunduğunda en büyük mükemmel olunamaz (Scotus, I975: 37I-2).

Aynı șekilde Sevgi, bir nesnenin canlanmasına kifayet eder. Bu, temelde Tanrısal iradeye müteallik bir durumdur. Bu sonucun her bir iradeye uygulanabilmesi için bazı kanıtlar ileri sürülmüștür: Birincisi irade, bütün iyilikleri içine alacak șekilde irade eder. Onu bir nesneyi sevmekte yanılgıya düșürecek bir günah ya da iyilik noksanlığı yoktur. İkincisi ise Aristoteles'in Fizik'indeki șu ifadelere dayanır: "Pratik bilimlerdeki erek, 
teorik bilimlerdeki ilkelerle aynı işlevi icra eder.” Yine Etik'te "Matematikteki postulalar davranıs biçimlerine de teșmil edilebilir.” Bu durumda teorik bilimlerdeki akıl zorunlu olarak pratik bilimleri de doğrular. Bu nedenle irade de zorunlu olarak davranıș biçimlerindeki nihai ereği tasdik eder. Diğer șeyler de iradenin sevdiği ve zorunlu olarak irade ettiği duruma ortak olur. Nihai erek bu nedenle zorunlu olarak irade edilir. Her bir değișken, değișmeyen bir șeye irca olunur. Aktların değișkenliği, değișmeyen bir aktın varsayıldı̆̆ı nihai ereğe kadar ulașan düzenle ilgilidir. İradenin iștirak ettiği bütün diğer objeler bakımından böyle bir akt özellikle varsayılır. Scotus, Augustinus'un Trinity'sindeki șu kanıtlamaya dikkat çeker: “'bundan' veya 'șundan' soyutlamak suretiyle bu iyiliği veya șu iyiliği alalım ve yapabilirsek Tanrı'nın zatına bakalım. Orada bütün iyilerin iyisi olan Tanrı'dan bașka bir șey göremeyeceğiz.” (Scotus, 1975: 37I).

Scotus övgü ve yerginin kaynağı açısından iradenin belirleme gücüne dikkat çeker. Ona göre 'övgüye değer' ve 'yergiye değer' veya daha genel anlamda 'ödüllendirilebilir' veya 'cezalandırılabilir' ifadeleri 'yüklenebilme' (imputable) anlamındadır. Bütün bunlar, öznenin özgür gücüne ișaret eder. Bu güç akıl ve irade kapsamı içerisinde olmasına rağmen yalnızca irade bir eylemin belirlenimli ve farklı olarak meydana gelmesini sağlayabilir. Diğer bütün aktif güçler doğal olarak akteder. Bu nedenle iki zıttan birine yönelik bir etkiyi kendi içinde belirler. Onun etkisi hususi bir etkiyi veyahut onun zıddını düșündügümüzde güneșin yerküre üzerinde farklı etkiler uyandırması gibi farklı etkiler doğurmaktaysa, bu durumda nedenin belirlenmiș olduğunu görürüz. Bu nedenle güneșin diğer etkilerle aynı șekilde otların büyümesine ve sıcaklığın sağlanmasına neden olması sağlanir (Scotus, 1975: 406).

Zıt etkilere göre irade yalnız bașına belirlenimsizdir. O iki șeyden biri konusunda kendi kendini belirler. İradi bir hareket farklı yönlere yöneliyorsa kontrolümüz dâhilinde değilse bu takdirde ödül ve cezayı hak etmez. Bu nedenle "yüklenebilme" çift yönlü bir ilișkiyi ifade eder. Bunların birincisi failin gücünü ve hâkimiyetini; ikincisi ise akta ve faile uygunluğu konu alır. İlk ilișki iyi olsun kötü olsun değișmeksizin devam eder. Hâlbuki ikincisi değișir. Gerçekte değișme șekilsel anlamda iyiden kötüye doğru değildir. İyilik ödül ve takdire yüklenirken kötülük ise suç ve cezaya yüklenir (Scotus, 1975: 406-7). 
Tanrısal irade her șeyin ilk nedenidir. İyilik, doğruluk ve ahlâkîlik ancak Tanrı tarafından istenilmiș olmak itibariyle mutlaktırlar. Eğer tanrısal iradeden bağımsız olarak mutlak olsa idiler Tanrı, kudretinde kendine tâbi olmayan bir kanun tarafından sınırlanmıș bulunacaktı (Weber, I998: I74). Tanrı, iradesi sonsuz olduğu için kendisini mutlak olarak ister. Kendisi için olanaklı olan her șeyi tek bir edimde isteyebilir ve isteyip istememede mutlak olarak özgürdür. Tanrı dünyayı sonsuz olarak istemiș olmalıdır yoksa dünyayı istememiș olduğu bir zaman olurdu ki bu Tanrı'da değișim ve eksiklik olduğu anlamına gelirdi (Thilly, 2000: 209).

Tanrı'nın iradesi mutlak olarak özgür olduğu için kavranılamazdır. Seçimleri için hiçbir olanaklı neden bulunamaz. Mantık, Tanrı'nın eylemleri için bir neden saptayamaz. İnsanın yapabileceğinin tümü evrendeki olguları deneyimsel olarak kendisine göründüğü gibi bilmektir. Çünkü Tanrı isteseydi bașka türlü bir evren de yaratabilirdi. Böylece Scotus Tanrı için dünyayı bir biçimde yaratmanın zorunlu olmadığını anlatan mümkün bir yaratılıș teorisi geliștirmiștir (Sahakian, I990: II4-5).

Çăgdaș Fransız Düșünürü R. Verneaux, Duns Scotus'un irade ve özgürlükle ilgili düșüncelerinin iz düșümü olabilecek bir hususa dikkat çeker. Ona göre Hristiyan teolojisinde iki temel esas vardır: İlahî öngörü ile özgürlügün ve ilahî müdahaleler (concours) ile özgürlügün uzlaștırılması. I. Özgürlük ve Öngörü (prescience): Tanrı'nın bizim fiillerimizi önceden gördüğü doğru bir ifadelendirme değildir. Zira onun ezelîliği ve ebedîliğii, zamanın bütün anlarının onun önünde eșit olarak bir șimdi olmasından ibarettir. O halde doğrusunu söylemek gerekirse Tanrı fiillerimizi önceden görmüyor. Her șey onun önünde cereyan etmiștir. Onun kararlarımızı bilmesi kararları özgür olarak almamıza hiçbir șekilde engel olmaz. 2. Özgürlük ve Müdahaleler: Tanrı yaratıklara var olușu verdiği gibi aynı șekilde onların eylemlerine de var olușu veriyor. Tanrı'nın müdahaleleri özgürlüğ̈ yok etmekten ziyade temellendirir, yani ona varlık kazandırır. Aziz Paul'ün ifade ettiği gibi, "Bizim yeterliliğimiz Tanrı'dan gelir.” Özgürlük, zekâ ve irade ile donatılmıș insanın yapısına hastır. Tanrı'nın buna ihanet etmesi çelișki doğuracaktır.

Scotus düşüncesinde Tanrı'nın iradesi konusuna dikkat çektikten sonra Tanri'nın iradesinin fiileriyle olan ilișkisine temas etmekte fayda var. Zira irade her gerçek failde bulunan bir vasıftır. Tanrı'nın ezeldeki 
iradesi "seçme" anlamını ifade eder. Genel olarak fiildeki seçimlere baktığımız zaman seçim sahibinin aynı zamanda irade sahibi olduğunu görürüz. Scotus'a göre irade fiille tahakkuk eder. $\mathrm{O}$ halde Tanrısal irade, fiilleriyle birlikte düșünülmelidir (Scotus, ı986: 208). Scotus, Tanrı'nın fiilleri konusunu da olumsallık teorisi bağlamında inceler. Opus Oxoniense'de irade ve eylem ilișkisine șu ifadelerle açıklık getirir: "İrademiz doğal olarak eylemden önce olduğu için bir șekilde olan bir șey aynı zamanda zıt bir șekilde de ortaya çıkabilir. Bu nedenle Tanrısal iradenin doğal olarak önceliği ve böyle bir eğilimde olması mümkündür. Örneğin sonsuzluğun șu anında zıt bir nesneye de eğilim gösterebilir.” Scotus'a göre özgür ve mümkün fiiller varsa özgür ve mümkün nedenler de olmalıdır. Yani bir neden bir fiille ya da onun zıddıyla belirlenir. Scotus, mümkün ve özgür nedeni irade ile özdeșleștirir ve bununla iradenin kendisini belirlediğini iddia eder. Burada vurgulanan husus, bir fiili sürdürmenin veya ondan yüz çevirmenin irade edilme olanağının bulunmasıdır. Bir nedenle zorunlu veya mümkün olarak bir failin belirlenmesine imkân tanınmaktadır. Farklı biçimlerde olmak üzere faillerin her ikisi de belirlenmiștir. Fail zorunlu olarak belirlenmișse failin aktları da zorunlu olarak belirlenmiștir. Scotus'a göre fail, eylemde bulunma veya bulunmama gücünü haizdir. Bu nedenle insan iradesi bir eylemde bulunma veya bulunmama ya da bir fail tarafından mümkün olarak belirlendiği sürece bașka bir fail tarafından belirlenebilir (Langston, I986: 37).

\section{Tanrı ve Ahlâk Yasası}

Scotus'un sistematik düșüncesi, zorunluluk teolojisi ve olumsallık teolojisi arasındaki ana yöntemsel ayrıma dayalı olarak bina edilir. Zorunlu önermelerin yanı sıra olumsal önermelerin bilgisi de bu doktrine bağlıdır. Gerçekte olumsal önermeler teolojinin en büyük kısmını olușturur (Scotus, I992: III).

Mantık ve onlotojideki Scotuscu dönüm noktası possibile logicum (mantıksal imkân) ideasidir. Scotus'un ortaya attığı eșzamanlı olumsallık teolojisi ve zorunluluk teolojisi kavramları bu temele dayanır. Eșzamanlı olumsallık teolojisi, onun bütün düșüncesine yayılmaktadır. Bir kimse onun etik'ini konu ettiğinde zorunlu ve olumsal teolojisinin ana hatlarını hemen kavrar: "Bu nedenle iddia etmekteyim ki olumsal bir șeyle ilgili 
zorunlu önermeler vardır. Çünkü 'Bir taș așağıya düșüyor' önermesi olumsaldır ve düșmeyle ilgili zorunlu doğrular içerir. Örneğin bu taş merkeze doğru ve düz bir çizgi halinde yol alır. Aynı șekilde 'Tanrı'yı severim' önermesi olumsaldır ve onunla ilgili zorunlu bir doğru da olabilir. Örneğin 'Tanrı'yı her șeyden çok sevmeliyim' önermesiyle ifade edilen tez șöyle kanıtlanabilir: 'Tanrı, düșünebileceğimizin en büyügüdür.' Bu nedenle Tanrı, her șeyden daha çok sevilir ve ben onu en yüksek düzeyde sevmeliyim. Böylelikle olumsal önermelerin bilgisine sahip olabilirim. Bu bilgi olumsal önermelerden çıkarılabilen zorunlu doğrularla ilgilidir (Scotus, 1992: 172).

Zorunlu ve olumsal teoloji arasındaki bu temel ayrım bakımından Duns'a göre etik'in iki türü olduğu ileri sürülebilir: Zorunlu etik ve olumsal etik. Buna göre zorunlu etik zorunluluk teolojisinin, olumsal etik de olumsal teolojinin bir parçasıdır. Scotus'un yeni ontolojisi olumsallık teorisi üzerine kuruludur. Ona göre etik yalnızca ahlâki iyilik temeline dayanır. Böyle bir etik iyilik, ontolojik olumsallık çerçevesinde bir bașkasına yönelir. Burada benmerkezcilikten bașkasına; komșuya ve doğal eğilimden açık uçluluğa doğru çift yönlü bir yönelme vardır. Bu ana çizgiler boyunca özgür olmak Scotuscu etik ve ontolojin temelini olușturur. Bu bakımdan günab işleme insanoğlu için özgür olma ve özgürlüğün temelinde vardır. Özgür olmak elbette Tanrı'ya atfedilecek temel bir esastır, fakat o kusurlardan arîdir (Vos, 2000: 202).

Scotus, Lectura III'te doğal yasayı kesin olarak tanımlamaya girișir. Ona göre doğal yasaya tabi olan șey zorunlu olarak etikteki temel aksiyomları takip eder. Bu tarzda çıkarsanan önermeler zorunlu olarak doğrudur. Çünkü onlar zorunlu önermelerden tümdengelim yoluyla çıkarsanmaktadır. Etik anlamda zorunlu ilkeler aynı zamanda doğal ilkenin bizatihi parçalarıdır. Scotuscu anlayıșın karakteristiği açısından zorunlu doğru ve irade birbiriyle irtibatlıdır. Zorunlu olarak doğru olan șey zihni ve iradi olmasa bile doğrudur. İradî bir iyilik veya bir irade aktı doğal yasanın iyiliğine tabi değildir. Çünkü doğal yasanın doğruluğu herhangi bir irade aktından öncedir. Onun doğruluğu doğal olarak bilinir. Bu tarz önermelerin zorunluluğu geniș anlamıyla analitiktir (Vos, 2OOO: 2I2-3). "İrade aktını tamamen dișta tuttuğumuzda ve Tanrısal akılla bu ilkeler kavrandı̆̆ında, bu takdirde güç ve bu ilkelere uygunluk irade aktından önce kavranır.” 
(Scotus, I992: III 37). Doğru, temelde doğal olarak doğrudur. Doğal doğrular (natural truths) bizatihi yani tabiatları gereği doğrudur. Scotus, etiğinde doğruyu tanımlarken doğası gereği doğruyu konu almaktadır (Vos, 2000: 2I3). Scotus'un bu yaklașımı Antik felsefenin mutlak akıl ve mutlak yasa bilgilerini bertaraf etmektedir.

Scotus etiğinin temelinde irade ile özgürlük arasında görülen olumsallık paradoksu ve iradenin akıl üzerindeki önceliği yer alır. Buna göre yaratma aktının önceliği, iyi olan șeyin tesisinde özgürlükle paralel bir rol oynar. Ahlâki doğruyu irade tesis eder. "Șeyler Tanrı'nın onları irade etmesi nedeniyle iyidir. Bu nedenle ahlâki doğruya doğal akılla nüfuz edilmez." (Quinton, I967: 369-96). Ancak, ona göre irade ile akıl arasında bir çelișki (antinomy) yoktur. Bununla birlikte zorunlu ve olumsal önermeler arasında ve bilgi ile iradenin birbiriyle ilișkisinde olmazsa olmaz bir ayrım vardır. İrade, zorunlu olmayan unsurlarla kurulmuş, ve olumsal bir alanda yer tutmuștur (Vos, 2000: 217).

Problemin çözümü olumsal etik ve zorunlu etik gibi temel kavramlarda olduğu gibi, eșzamanlı olumsallık (synchronic contingency) ile eșzamanlı zorunluluk (synchronic necessity) arasındaki temel ayrıma dayanmaktadır. Zorunlu etik bakımından iyilik iradeye dayalı olamaz. "A Tanrı'yı sever." önermesinde olduğu gibi olumsal etik önermeler dahi "Tanrı sevilir." önermesinde olduğu gibi zorunlu önermelerin ve "A vardır; Tanrı’yı bilir.” gibi zorunlu doğruların birlikteliğine dayanır. Zorunlu önermeler bizatihi iradeye dayalı değildir. Duns Scotus ve St. Thomas arasındaki temel ayrım, felsefedeki idealizm ve realizm arasındaki süregelen ihtilafa dayanır. İdealizm açısından realizmin zafiyeti eșyanın tabiatını reel olarak kavrama iddiasına dayanır. Bu yaklașım kușkucu bir kritisizmi doğurur. Burada Scotus'un teolojik voluntarizmi öne çıkmaktadır. Scotus özgürlügü teolojik önermelerde aramaktadır. Fakat böyle bir felsefi bașlangıç noktasının seçimine felsefi bir yolla karar verilemez. Duns Scotus ile St. Thomas arasındaki bu derin teorik ayırıma rağmen bunların pratik izdüșümleri arasında çok sınırlı bir düzeyde ayırım görülmektedir (Vos, 2I8-9)).

Scotus felsefesinde doğrular ister zorunlu isterse olumsal olsun olumsal bir yolla keșfedilirler. Eșzamanlı olumsallık teorisi Scotus teolojisinin ve felsefesinin sistematik yapısını biçimlendirmiștir. Bu nitelikler onun karakteristik terimlerinin ayırt edici anlamlarını olușturmaktadır. Bu 
nedenle pek çok geleneksel terim yeni anlamlar kazanmaktadır. Örneğin, Scotus, Peter Lombard'ın "Tanrı yarattı̆̆ı șeylerin daha iyisini yaratabilir miydi??" sorusu yerine "Tanrı yarattığı șeyleri olduğundan bașka türlü yaratabilir miydi?" sorusunu koyarsak daha tatminkâr bir cevap alacağımızı savunur. Ona göre "Tanrı, șeyleri düzensiz olarak yarattı." önermesinin öncülü yanlıș olduğu için sonuçları da yanlıș olmaktadır. Öte yandan șeylerin bașka türlü yaratılması, kendisiyle çelișen bir șey olmadığı gibi dünyanın da bu șekilde yaratılması zorunlu değildir (Scotus, 1986: 255).

Tanrısal iradenin iyilikle hükmetme zorunluluğu yoktur. Seçim, iyiliğin aksine Tanrı'nın iradesiyle ilgili bir konudur. Tanrı bir șeyi irade ederse bu șey iyidir. Tanrı irade etmiș olduğundan bașka ahlâkî yasalar irade etmiș olsaydı, bu diğer yasalar geçerli olurdu. Çünkü erdemlilik onun iradesindedir. Tanrı'nın irade ettiği kadarının dıșında erdemlilik tașıyan bir yasa yoktur (Gilson, 1978: 46I).

Scotus, yukarıda yeniden düzenleme yoluna gittiği soruya ilişkin olarak akıllı ve iradî olan her bir eyleyen için, bir aktı șöyle ya da böyle gerçekleștirmenin bir zorunluluk olmadığını vurgulamakla birlikte söz konusu aktın doğru ve yasal olanla uyumunu gerekli görür. Bu nedenle Tanrı'nın yanı sıra bütün özgür eyleyenler ya adil bir yasanın zorlamalarılla uyumlu olarak aktederler ya da bu yasanın dıșında veya karșısında olurlar. Her ne zaman yasa ve onun doğruluğu eyleyenin gücü dâhilinde ise fail, șeyleri, bu doğru yasanın zorladığından başka türlü de düzenleyebilir ve düzenli olarak sürdürebilir. Scotus șeylerin doğru olarak düzenlendiği bazı genel yasaların Tanrisal akılla değil de Tanrisal iradeyle önceden kurulduğunu savunur. Ancak akıl, Tanrısal iradeye örneğin "Șeref sahibi bir insan öncelikle kibar olmalıdır" tarzında bir yasa sunduğunda bunu özgür iradesi ile arzu ederse bu da diğer yasalar gibi doğru ve mutlak bir yasa olur. Bu nedenle Tanrı doğru yasalara uygun olmayan pek çok șey yapabildiği sürece önceden vaz edilen yasaların dișına çıkmış olur. Bu durumda Tanrı, mutlak gücüne uygun olarak edimde bulunur, denilir. Tanr'nın meydana getirdiği șeyler kendi kendisiyle çelişmediği için veya gerçekleștirdiği edimler bir zıtlık içermediğinden mutlak gücü ile uyumlu olarak edimde bulunduğu söylenebilir. Scotus'a göre tesis edilmesi Tanrısal iradenin kabulünün dıșında olan bașka bir meșru yasa yoktur. Bu nedenle Tanrı yalnız tikel değil, bunun yanı sıra tümel bir emirle ya da hukuki bir yasa ile 
emrettiğinden bașka türlü aktedebilir. Bu durumda da halen düzenli olarak aktetmiş olur. Çünkü mevcut düzenin ötesinde olan Tanrı'nın mutlak gücü, yapabildiği șeyleri ancak düzenli olarak yapabilir (Scotus, 1986: 257).

Burada, Tanrı'nın emredici gücü derken tümel bir yasa tarafından kurulan bir düzen kastedilmektedir. Tanrı için örneğin kefaretini ödemediği takdirde lanetli olarak ölecek olan bir günahkârın gerçekte bağışlanmadı̆̆ ama bağıșlanmasının mümkün olduğu açı bir olgudur. Ancak kuşkusuz Tanrı çoktan lanetlenmiș olan Yahuda'yı bağışlamayacaktır. (Fakat Tanrı'nın mutlak gücü açısından bu imkânsız değildir. Bu durum kendi içinde bir çelişki içermez.) Bu nedenle bașka bir günahkârın bağıșlanması mümkün iken Yahuda'nın bağıșlanması mümkün değildir. Yahuda yalnızca Tanrı'nın mutlak gücü ile bağıșlanabilir. Fakat Yahuda'nın kurtulușu, onun tesis edebileceği bașka bir düzende Tanr'nın emredici gücü sayesinde sağlanabilir ((Scotus, 1986: 259-6I). Tanrı, aklıselimin ve ortak bilincin gösterdiğinin aksine bir akt gerçekleștirmez. Çünkü Tanrı daima hakkaniyetli bir irade (ordinatissime volens) sergiler (Scotus, 1986: 8-9).

Bu bağlamda Scotus Ordinatio'da "Moral iyilik Tanrı'nın iradesiyle uyumlu mudur?" sorusuna cevap arar. Peter Lombard Sentences'in ilk kitabında irademizin Tanrı'nın iradesiyle uyumlu olduğunu ileri sürmektedir. Scotus, Lombard'n temel argümanının zıddını savunur: "Yahudiler, İsa'ya eziyet etmeyi ve onu öldürmeyi irade etmișlerdir. Bunu aynı șekilde İsa da irade etmiștir ancak Yahudiler yine de günahkârdır." Zira İsa'nın duası şöyledir: 'Baba onları affet! Çünkü onlar ne yaptıklarını bilmiyorlar.' Scotus'a göre "iyilik yalnızca objeye bağlı değildir. Bașta gaye olmak üzere bütün diğer koșullar da gözetilmelidir.” (Scotus, I986: 54).

İnsan iradesi, daha genel anlamda yaratılmış irade, yaratılmayan iradeyle uyumlu olduğu sürece moral bakımdan iyidir. Yaratılmıș irade, yaratılmamıș iradede olduğu gibi her durumda iyiyi irade etmek zorunda değildir. Çünkü faillerin bulunduğu yer temelde farklıdır. Yaratılmış irade, yaratılmamıș irade ölçüsünde bir iyiyi sevmeye uyumlu değildir. Aktların yoğunluğunda gerçekte büyük farklar vardır. Yaratılmıș ve yaratılmamış, irade arasında en azından aktın ve objenin iyiliği açısından her bakımdan bir uygunluk olsa dahi irade atkının iyiliğinin gerektirdiği diğer durumlarda bir orantisızlık olmaya devam edecektir (Scotus, 1986: 237).

Scotus kötülerin cezalandırılması hususunda Tanrı'nın adaletiyle ve 
rahmetiyle nasıl muamelede bulunacağına ilișkin olarak dört hususu gündeme getirir: Birincisi Tanrı'nın katında adaletin olup olmadığı; ikincisi Tanrı'nın katında rahmetin olup olmadığı; üçüncüsü Tanrı'nın katında adaletin rahmetten ayrılıp ayrılmayacağı; dördüncüsü kötülerin cezaland1rılmasında Tanrı'da adalet ve rahmetin mutabık olup olmayacağı. Adalet temelde Tanrı'nın yaratılanlara karșı mükâfat ve ceza ile muamelede bulunmasına atfedilir. Kısacası Tanrı, yarattığı kullarına müstahak oldukları șeyleri verir. Scotus, Anselm'den șöyle bir tanım aktarır: “Adalet, iradenin doğruyu -bizatihi doğru olduğu için- gözetmesi (observed), koruması (preserved) ve yerine getirmesi (served)'dir." (Scotus, I986: 55). Latincedeki "servetus" tanımda geçen üç anlamın hepsini de çağrıștırabilen bir sözcüktür. Adalet iki hakkı tesis eder. Birincisi diğerlerine de teșmil edilebilmesi bakımından evrenseldir. Yasanın genel ve belirli düzenlemeleri yasa koyucu tarafindan tayin edilir. Scotus bunu pek çokları gibi 'meșru hak' (legal justice) olarak adlandırır. İkincisi ise özel (particular) hak'tır. Yasaya ait bazı özel yönlerin doğruluğunu içerir. Bunlardan ilki yani meșru hak Tanrı tarafından postula edilir. Ancak meșru ve özel olmak üzere saydığımız iki hak Tanrı'da aynı șeyi ifade eder. Zira Tanrısal iradenin doğruluğuyla iyiliği birbirine özdeștir (Scotus, I986: 24I-3).

Scotus, Anselm'in Proslogion'unda geçen bir sözünü aktarır: "Yalnızca irade ettiğin șey adildir ve yalnızca irade etmediğin șey adil değildir.” (Scotus, I986: 247). Zihin determine olarak ikincil objelerden birine eğilimlidir. Fakat iradede durum böyle değildir. Bir kimse ilahî iradenin birincil aktına eğilimlidir. İrade ikincil objelerin her birinden önce kendini determine eder. Zihin, bazı mümkün fiilleri, iradenin onları irade etmesinden önce kavrayabilir. Ancak bu kavrayıs,, belli bir șeyin olması gerektiği tarzında değildir. Yani bu kavrama (to apprehend) dikte etme anlamı taşımaz. Bu kavrayıs, gerçekte iradeye yansız (neutral) olarak yöneltilmiş, bir tekliften ibarettir. Bunun gerçekleșmesi yönünde irade kesin kararı verdikten sonra ortaya çıkabilecek olumsallarla ilgili olarak zihin, gerçekleșmesi isabetli olan șeyi kavrar. Örneğin “Tanrı sevilmelidir.” önermesi. İrade bununla uyușmazlık edemez. İrade bunu doğrudan takip etmemekle birlikte doğal olarak onu irade etmeye zorlanır. Özetleyecek olursak bir șeyin gerçekleșmesine yönelik eğilim zihin açısından doğaldır (naturally); oysa irade açısından özgürcedir (freely). Bu güçler daima uyum içindedir- 
ler. Ancak aynı objeye farklı cihetlerden yönelirler. Tıpkı muhayyile (imagination) ve zihnin (intellect) bir objeye öncekinin tekil, sonrakinin ise tümel olarak eğilim göstermeleri gibi aralarında bir ayrıșma ortaya çıkar (Scotus, 1986: 25I).

Scotuscu teolojideki irade ve ahlâk ilișkisini saptamamızı kolaylaștıran bir diğer soru da șudur: "Tanrı, evreni yarattığından bașka suretle de yaratabilir miydi?” Bu soruyu pek çok düșünür tartıșma konusu yapmıștır. Pierre Abelard șöyle der: "Tanrı evreni olabilecek en iyi zamanda ve en iyi șekilde yaratmıștır.” Bu yaklașıma göre mantıksal olarak yaratmanın mevcut haliyle zorunlu olduğu dolayısıyla olumsal olmadığı vurgulanmaktadır. ${ }^{5}$ Scotus da pek çok düșünür gibi potentia absoluta'daki gücü herhangi bir kısıtlama veya kayıtlama olmaksızın basit ve mutlak anlamda ele alır. Ona göre Tanrı, bir șeyi kendisiyle çelișkiye düșmeksizin yapar. Șeylerin bașka türlü olabilmesi ne Tanrı'nın kendisiyle çatıșması ne de dünyada zorunluluğun hâkim olduğu anlamını tașır. Potentia ordinata (takdir edici güç) daima tek bir tazda tanımlanamaz. Bu nedenle ordinata farklı biçimlerde tercüme edilebilir. Yaygın olarak kabul edilen anlam Tanrı'nın fiilen (de facto) takdir edici olmasıdır. Scotus, ordinate ve ordinatissime kavramlarını 'düzenli' ve 'metodik' olarak aktetme anlamlarında alır ve bu terimleri ordinatissime volens (metodik olarak irade eden) tarzında Tanrı'ya atfeder (Scotus, I986: 56-7).

Tanrı mutlak güç sahibi olarak teoride (de jure) her șeye güç yetirendir. Ancak o iyiliklerinde adaletlidir. Bu nedenle Tanrı bașka türlü yaratmakta özgür olmasına rağmen iyiliğini ihlal etmekte özgür değildir. O kendisinin doğal özgürlüğe (innate liberty) sahip iradesinin tam yetkinliğinin bir gereği olarak adalet eğilim veya yöneliminin de dıșına tașmaz. Şimdi “Tanrı evreni yarattı̆̆ından bașka suretle de yaratabilir miydi?” sorusunu tekrar gündemimize alacak olursak soru Scotus'un genel irade anlayıșı çerçevesinde șöyle yanıt bulur: "Șeyler, Tanrı onları irade ettiği için iyidir. Zira aksi geçerli değildir. Dolayısıyla ahlâki doğrulara doğal nedenlerle erișilemez.” (Scotus, I986: 57).

\footnotetext{
Bu zorunlulukçuluğu dile getiren Pierre Abelard, Kilisenin baskıları nedeniyle buna ilișkin sözlerini geri almıștır. Ancak ı3. yüzyılın ikinci yarısından itibaren Paris Üniversitesi'nde yaygınlık kazanan İbn Rüștçülüğün etkisiyle bu yaklașım tekrar aktüel hale gelmiștir. Daha sonra İbn Rüșd'ün görüșleri de Kilise tarafından yasaklanacaktır. İbn Rüșd'ün Aristoteles yorumu için bkz. Altuner, 20I7: I-I7.
} 
Scotus “Tanrı'nın mutlak (absolute) gücü takdir edici (ordained) gücünü aşar mı?” sorusunu ise Tanrı'nın yanı sıra bütün irade sahiplerine teșmil eder ve șöyle bir hukuki yargıya varır: Bir kimse mutlak gücüne göre fiilen akteder; takdir edici gücüne göre ise teorik (de jure) olarak akteder. Bir fail (agent) olarak Tanrı bulunduğundan farklı bir aktta da bulunabilir. Bu durumda bașka bir doğruluk yasası kuracağı için onun tarafından konulan yasa doğru olacaktır. Çünkü ortaya çıkıșı ilahi iradenin kabulüyle olmayan hiçbir yasa doğru değildir. Scotus on emir'in ikinci tablosuna ilișkin olarak da iki hususa dikkat çeker. Birincisi Tanrı'nın varlığı bizatihi bilinen ilkelerden doğal bir nedenle çıkarılabilirse de zihinsel konularda yeteneği olmayan bilgisiz insanlar için bu bilgi yalnızca vahyedilmis yasa (revealed law) yoluyla bilinir. Aynı sonuç yalnızca bir miktar akıl yürütmeden sonra bilinebilen moral doğru (moral truths)'lara da uygulanabilir. İkincisi günahkâr itiyatlar zihni kör eder. Bu nedenle ahlâksız insan doğal yasaya karșı içine düștüğü sapkınlığın farkına varmayabilir. Bu nedenle bu hususlar zorunlu olarak açıklanır. İște örneğin șehvet düșkünlüğünün günah olușu ikinci tabloda yasaklanmıștır. Dolayısıyla bir kimsenin bu tür hususların kendiliğinden (per se) bilemeyeceği kabul edilebilir (Scotus, I986: 255-8).

Scotus On Emir'deki ${ }^{6}$ bütün ilkelerin doğa yasasına ait olup olmadığ hususunu tartıșma konusu yapar. Ona göre On Emir'deki ilkeler iki kısma ayrılır. Birincisi dar veya özel (strict or proper) anlamda doğal yasaya ait

6 Musa'ya Sina Dağı'nda Tanrı tarafından 2 taș tablet üzerinde verildiği söylenen on emir, Eski Ahit'in Çıkıș (Eksodos) kitabının 20. babında yer almaktadırlar:

I. Karșımda bașka ilahların olmayacak.

2. Kendin için oyma put, yukarda göklerde olanın, yahut așağıda yerde olanın, yahut yerin altında sularda olanın hiç suretini yapmayacaksın, onlara eğilmeyeceksin ve onlara ibadet etmeyeceksin.

3. Yehova'ın Rab'in ismini boș yere ağıza almayacaksın.

4. Sebt gününü takdis etmek için onu hatırında tutacaksın. Altı gün ișleyeceksin ve bütün ișini yapacaksın, fakat yedinci gün efendin Rab'e Sebttir. Sen ve oğlun ve kızın, kölen ve cariyen ve hayvanların ve kapılarında olan garibin hiçbir iș yapmayacaksınız. Çünkü Rab gökleri, yeri ve denizi ve onlarda olan bütün șeyleri altı günde yarattı.

5. Babana ve anana hürmet edeceksin.

6. Katletmeyeceksin.

7. Zina etmeyeceksin.

8. Çalmayacaksın.

9. Komșuna karșı yalan șehadet etmeyeceksin.

IO. Komșunun evine tamah etmeyeceksin, komşunun karısına yahut kölesine yahut cariyesine, yahut öküzüne, yahut eșeğine, yahut komșunun hiçbir șeyine tamah etmeyeceksin. http://tr.wikipedia.org/wiki/On_Emir. 
olan yani sözlerinin (terms) ve hükümlerinin (conclusions) bunu zorunlu olarak gerekli kıldığı pratik ilkelerdir. İkincisi sözlerin ikincil veya genel (secondary or broder) anlamı yani sözlerin anlamı zorunlu olarak ilk ilkelerden çıkmasa da sıradan bir zihin tarafından zorunlu olarak anlașılabilen ilkelerdir. Fiillerin moral bakımdan iyiliği veya kötülüğü ve bunların emredilmesi veya yasaklanması yalnızca Tanrı'nın onları irade etmesi nedeniyle değildir. Bu fiiller moral açıdan iyi veya kötü oldukları için Tanrı tarafından her biri ayrı olarak emredilmiștir veya yasaklanmıștır. On Emrin ne kadarı dar (strict) ne kadarı geniș (extended) anlamda doğal yasaya ait olduğu konusu da Scotus tarafindan ayrıca tartıșma konusu yapılmıștır. Scotus konuya ilișkin düșüncesini șöyle özetler: "İlkin biz ikinci tabloya (second table, On Emrin son yedi ilkesi) ait ilkelerin hepsinin mutlak anlamda doğal yasalara ait olduğunu kabul etmiyoruz. İkincileyin ilk iki ilkenin mutlak anlamda doğal yasalara ait olduğunu kabul ediyoruz. Üçüncüleyin İlk tablonun (first table, On Emrin ilk üç ilkesi) üçüncü ilkesinin konumu hususunda bazı kușkular vardır. Dördüncüleyin, geniș (broadly) anlamda ilkelerin bütününün doğal yasaya ait olduğunu kabul ediyoruz." (Scotus, I986: 6I-3).

Scotus On Emir'deki ilkelerin doğal yasalara aidiyeti hususundaki genel yaklașımını șöyle özetler: Doğal yasalara ait olan bu ilkeleri Tanrı'nın askıya alması düșünülemez. Ancak Tanrı bazı hususlarda bu ilkelerin aksini gerçekleștirebilmiștir. Buna göre genel olarak doğal yasaya ait olan șey ya terimleri itibariyle doğrudan bilinen pratik ilkelerdir ya da bu ilkeleri takip eden zorunlu hükümlerdir. Bu nedenle Tanrı onları yanlıșlayamaz. Yani meșru olmayan bir șeyi meșru yapamaz. Özellikle cinayet ișlemek, hırsızlık yapmak ve zina etmek On Emir prensiplerine terstir ve Çıkıs, babında (Exodus, 2O:I3) açıkça ifade edilmiștir: 'Öldürmemelisin' gibi. Ancak zaman zaman Tanrı'nın bunları askıya aldığı görülmüștür. İbrahim'in oğlunu kurban etme bahsi Yaradılıș babında (Genesis: 22) açıklıkla yer alır. Yine Çıkıș babında (Exodus, II:2, I2:35) İsrailoğullarına yönelik olarak Mısırlıların (Egyptians) mallarını çalma emri yer alır. Bunların yanı sıra Hosea ${ }^{7}$ I'de “Zina çocukları yap!” emri yer almaktadır. Scotus konuya

Efraim diye bilinen İsrail'in kuzey Krallığının bașkenti Samiriye İ.Ö 722 yılında Asurlular tarafından ele geçirildi. Peygamber Hoșea bu olaydan önceki sıkıntılı günlerde ortaya çıktı. Özellikle putperestlik ve sadakatsizlik konusuna değindi. İsrail halkının Tanrı'ya sırt çevirip bașka ilahlara yönelmesi zinayla özdeșleștirildi. Nitekim Hoșea Tanrı’yla İsrail 
ilișkin olarak Aziz John'un Kitab-1 Mukaddes'te (ch. 2, vv. 3-7) yer alan mektubuna dikkat çeker: "Tanrı'ya ait bilgimizden emin olmanın yolu, onun emirlerini yerine getirmekten geçer. Çünkü onun sözünü tutan (keep his word) kimse gerçekte Tanrı'nın sevgisini kazanmıştır ve bu sevgi onu yetkinleștirir. 'Tanrı'ya dair bilgim var.' iddiasında bulunan insan onun emirlerini yerine getirmiyorsa yalancıdır. Bununla size yeni bir emir yazıyor değilim. Zira bu öteden beri (from the start) sahibi olduğunuz kadim bir emirdir.” (Scotus, I986: 27I). Scotus'a göre konuyla ilgili bu örnekleri göz önüne alan kimse On Emrin doğal yasaya ait olduğunu düșünebilir. Ona göre yukarıda geçen ifadelerden özetle șöyle bir yargıya varılabilir: "Emredilen șeyler yalnızca emredildiği için iyi değildirler; bilakis onlar bizatihi iyi oldukları için emredilmişlerdir. Bunun gibi yasaklanan șeyler de yasaklandığı için kötü değil; aksine bizatihi kötü oldukları için yasaklanmıștır.” (Scotus, I986: 273).

Scotus doğal yasa ile ilgili Gratian Kararları"'nın temel kriterini kabul eder. Gratian Kararlarında buna ilișkin olarak șöyle denilmektedir: "Doğal yasa, rasyonel varlıkların başlangıcından itibaren yürürlüktedir. Zaman içinde değișmeyen bir sabitlik içindedir.” Ancak Scotus bu kriteri On Emrin ikinci tablosundaki ilkelere teșmil etmez. Oysa ona göre birinci tablonun ilkeleri için durum farklıdır. Çünkü bunlarda bir obje olarak doğrudan Tanrı dikkate alınır. "Tanrı'dan bașka ilah tanımayacaksın!", “Tanrı'nın ismini boș yere ağzına almayacaksın!”, “Tanrı'ya saygısızlıkta bulunmayacaksın!" ilkeleri zorunlu olarak itibar edilmeyi gerektirdiği için doğal yasaya aittir. Sonuç olarak Tanrı, hiç kimseye bu ilkelerde emredilen ve nehyedilen hususlara zit davranma muafiyeti tanımaz (Scotus, I986: 277). Zira "Tanrı sevilmelidir.” önermesi "Tanrı'dan nefret edilmemelidir." önermesini zorunlu olarak takip eder. Dolayısıla bu ilkeler On Emrin birinci kısmına yani tam veya hususi anlamda doğal yasaya ait olan ve söz ve hükümlerin zorunluluk tașıdı̆̆ 1 pratik ilkelerdir.

halkı arasındaki ilișkileri sergilemek için Tanrı tarafından zina eden bir kadınla evlendirilmeye yönlendirildi.

8 Bolognalı bir keșiș olan Johannes Gratian'ın II40'lar dolayında yayınladığı ve o zamana kadar gelen kilise hukuku çalıșmalarının bir derlemesi olan Decretum'dur. Bir derleme olması nedeniyle Decretum, teoloji ve hukuk normları gözetilerek ve daha çok hukukla ilgili olan faiz, fiyat, monopol gibi konulara, Hristiyanlık teolojisinin ilkeleri bağlamında yeniden yorumlar getirmiștir. Küçükalay, 2017, 178 . 
Hatırlanacağı üzere On emrin ikinci kısım ilkeleri, sözlerin ikincil veya genel (secondary or broder) anlamı yani zorunlu olarak ilk ilkelerden çıkmasa da sıradan bir zihin tarafından zorunlu olarak anlașılabilmeyi ifade ediyordu. Scotus konuya ilișkin olarak savunduğu temel kanıtları șöyle siralar:

I. İkinci tablodaki ilkeler dar anlamda doğal yasaya ait değildirler.

2. Tanrı'nın varlığı doğuștan gelen ilkelerden olması münasebetiyle doğal akılla bilinebilir. Ancak zihinsel konularda yeteneksiz olan kimseler bu bilgiye yalnızca vahiy yoluyla ulașırlar. Kitab-1 Mukaddes'te Havarilerden biri Yahudilere șöyle seslenir: "Kendisine Tanrı'nın bilgisi ulașan kimse onun varlığına inanmak zorundadır."(Hebr. II) (Scotus, I986: 285).

3. Tanrı'nın, İsrailoğullarının Mısırlıların mallarını yağmalamasına salık vermesi bașkasına ait olan bir șeyle ilgili olarak “çalma!” ilkesini askıya almaz. Çünkü Tanrı bu malların asıl sahibidir. Bu malların yasal sahipleri bunu irade etmeseler bile Tanrı o malları onlardan alıp bașkasına verebilir. Diğer bir açıklama șöyledir: İsrailoğulları, Mısırlıların emrinde çalıștırıl1yorlar ve Misırlılar onlara ücret takdir etmiyorlardı. Bu nedenle İsrailoğulları onlardan aldıkları șeyleri zaten çalıșma ücreti olarak hak etmișlerdi. $\mathrm{Bu}$ durumda yüce yargı Mısırlıları buna zorladı. Yahudiler de yüce yarg1nın izniyle bu șeyleri kabul ettiler. Onlar bu șeylere adil ve meșru olarak el koydular (Scotus, 1986: 285-7).

Duns Scotus'a göre Tanrı'nın her zaman en iyiyi seçmesi Tanrı'nın mutlak bir zorunlulukla hareket etmesini gerektirmez. Tanrı'nın iyi olanı seçmesinde bir zorunluluk söz konusu ise de bu, mantıksal bir zorunluluk değil, Tanrı'nın iyilik ve adalet sıfatlarının gereği olan ahlâkî bir zorunluluktur. Ona göre Tanrı'nın iyiyi seçmesinin bir bakıma zorunlu olduğu söylenebilir. Fakat bu zorunluluk imkâna zıt bir zorunluluk değildir (Copleston, 53I-3). Öyle anlaşılıyor ki Scotus, iradeciliği metafiziğin yanı sıra ahlâkî alana da tașımıștır. Buna göre her șeyin ilk nedeni olan tanrısal irade aynı zamanda yaratılmıș bütün zihinlerin de en yüksek yasası olmak durumundadır. İyi ve doğru sadece Tanrı tarafından irade edilmiș olmak bakımından mutlaktır. Buna göre Tanrı insanlara ilettiği ahlâk yasasının yerine bașka bir yasa da gönderebilirdi. Hatta insanları bu yasalardan muaf da tutabilirdi (Cevizci, 1999: 259-60). 
Yine kötülüğe meyledebileceklerini önceden görmesine rağmen Tanrı'nın, yaratıklarından bazılarına özgürlüklerini kullanma fırsatı bahșetmesi genel nizam ve iyilikle uygunluk içindedir. Tanrı'nın hususi fiilleri en iyi șekilde kutsal metinlerde ve o inançların kendilerine ait teolojilerinde ele alınabilir. İlâhî fiilin așkın kökeni Tanrı'nın șahsiyet olarak tasavvur edilmesiyle açı̆̆a çıkar. Şahsiyet olmayan panteist bir Tanrı, meydana gelen her șeyin ardındaki güç olabilir fakat hususi fail olamaz. Dünyada fiilde bulunması için Tanrı'nın muayyen hadiselerden ve șartlardan haberdar olması zorunludur. Dahası Tanrı'nın hadiselerin akıșını etkileyecek veya onlara tesir edecek kudrette olması gerekir: Tanrı fiili, bir hadisede Tanrı'nın hususi olarak müdahalesiyle ortaya çıkar. İlâhî yasa kapsamına giren önemli bir konu da duadır. Ancak dua pek çok soruyu gündeme getirir. Ĕ̆er Tanrı bizim ona söylememiz mümkün olan her șeyi zaten biliyorsa bu takdirde dua etmenin anlamı nedir? Dualarımızın Tanrı'yı aksi takdirde yapmayacak olduğu bir șeyi yapmaya sevkettiğini farz etmemiz mümkün müdür? Biz Tanrı'ya dua ettiğimizde gerçekten ne olup bitmektedir? (Peterson vd., 20ı6: 2ı6-7). "Tanrı'nın belli bir olaya sebep olduğunu söylemek tam olarak ne anlama gelmektedir?” Birçok teist pek çok olayın geniş anlamı itibariyle Tanrı'nın fiili olduğunu kabul eder. Nitekim evreni yaratan, evrendeki neden sonuç ilișkisinin dayandığ ${ }_{1}$ 'kanunları' koyan ve ilâhî kudretiyle bu ilișkinin ayakta kalmasını sağlayan Tanrı'dır." (Peterson vd., 20I6: 244). ${ }^{9}$

Scotus, God and Creatures kitabında Tanrı'nın iradesi ve insanın özgür iradesi arasındaki ilișkiyi doğrudan ve derin bir tartışmaya tabi tutar. "Ay$\mathrm{n} ı$ fiil ve nesneyle ilgili iradenin özgürlüğ̈ ve doğal zorunluluk nasıl bağdaşır?”ın yer aldığı I6. Soru, tamamen bu konuya hasredilmiștir. Augustinus'un yazıları bu sorunun tartıșılmasında anahtar rolü oynar. Scotus, Augustinus'tan iki alıntı ile bu bahse girer. İlk olarak doğal zorunlulukla irade özgürlüğünün bağdașmazlığını göstermek üzere suçlulukla iradilik arasındaki bağlantılara değinir. İkinci olarak mutlak bilgiye sahip olsa bile Tanrı'nın özgür olușuna ve irade ederken, doğal zorunluluğun özgürlükle karşıt bir konumda bulunmadı̆̆ına dikkat çeker (Scotus, I975: 369-70).

9 Ortaçağ filozofları Tanrı'nın "birinci dereceden neden" olmasını, ilâhî kudretin varlıkta tuttuğu mahlukata ait, "ikinci dereceden neden" olmadan ayırmıșlardır. Peterson vd., 2016: 270 . 
Scotus iradenin herhangi bir aktında zorunluluk bulunup bulunmad1ğını tartıștıktan sonra önemli bir ayırım yapar. O değișmezliğin zorunluluğu ile kaçınılmazlığın zorunluluğunu birbirinden ayırır. Değișmezliğin zorunluluğu "iradede aynı andaki bir değișimi dıșta tutar. Tanrısal irade bir sonraki anda șimdikinden farklı bir biçimde irade edebilir.” Bunun anlamı, Tanrısal irade bir șeyi bir kez irade ettiğinde bundan geri durması mümkün değildir. Kaçınılmazlığın zorunluluğu ise değișikliği ve ardıșıklığı dıșta tutmakla kalmayıp Tanrısal iradenin irade ettiğinden bașkasını devre dıșı bırakmasıdır.” (Scotus, I975: 376-7). Tanrısal irade her neyi irade etmișse onu irade etmek zorundadır. Aksini irade edemez. Açıktır ki kaçınılmazlığın zorunluluğu, değișmezliğin zorunluluğundan daha kavidir. Scotus Tanrı'nın iradesiyle ilișkilendirildiğinde iki zorunluluk arasında ayırım yaparken açıktır ki bu ayrımı insan iradesine de uygulamayı düșünmüștür.

\section{Sonuç}

Scotus, her șeyin zorunlu ve değișmez olduğunu iddiasını, mantık örgüsü güçlü olan bir teoriyle çürütme yoluna gitmiștir. Bu bağlamda "eșzamanlı olumsallık” diye kavramlaștırdığı parlak bir keșifte bulunmuștur. Scotus'un klasik Hristiyan anlayıșını derinden etkileyen bu olumsallık teorisinin esası, fiilî gerçekliğin gerçekte olandan farklı da olabilmesine dayanır. Olumsal gerçeklik teorisi, bir nevi Hıristiyan düșüncenin Antik Yunan düșüncesinden kurtulmasını ifade etmektedir. Olumsallık teorisinin özünü zıtların aynı anda mümkün olması olușturur. İrade bir șeyi belli bir anda irade etmenin yanı sıra etmeyedebilir.

Scotus'un sistematik düșüncesi, zorunluluk teolojisi ve olumsallık teolojisi arasındaki ana yöntemsel ayrıma dayalı olarak olușturulur. Zorunlu önermelerin yanı sıra olumsal önermelerin bilgisi de bu doktrine bağlıdır. Gerçekte olumsal önermeler, teolojinin en büyük kısmını olușturur. Zorunlu ve olumsal teoloji arasındaki bu temel ayrım bakımından Scotus'a göre ahlâkın iki türü olduğu ileri sürülebilir: Zorunlu ahlâk ve olumsal ahlâk. Buna göre zorunlu ahlâk, zorunluluk teolojisinin, olumsal ahlâk da olumsal teolojinin bir parçasıdır. Onun yeni ontolojisi olumsallık teorisi üzerine kuruludur. Problemin çözümü, eșzamanlı olumsallık ile eșzamanlı zorunluluk arasındaki temel ayrıma dayanmaktadır. 
Scotus'a göre tesis edilmesi Tanrısal iradenin kabulünün dıșında olan bașka bir meșru yasa yoktur. Bu nedenle Tanrı yalnız tikel değil, bunun yanı sıra tümel bir emirle ya da hukuki bir yasa ile emrettiğinden bașka türlü aktedebilir. Bu durumda da halen düzenli olarak aktetmiș olur. Çünkü mevcut düzenin ötesinde olan Tanrı'nın mutlak gücü, yapabildiği șeyleri ancak düzenli olarak yapabilir. Tanrı mutlak güç sahibi olarak teoride her șeye güç yetirendir. Ancak o iyiliklerinde adaletlidir. Bu nedenle Tanrı bașka türlü yaratmakta özgür olmasına rağmen iyiliğini ihlal etmekte özgür değildir. O kendisinin doğal özgürlüğe sahip iradesinin tam yetkinliğinin bir gereği olarak adalet eğilim veya yöneliminin de dișına tașmaz. Scotus On Emir'deki bütün ilkelerin doğa yasasına ait olup olmadığı hususunu tartıșma konusu yapar. Ona göre On Emir'deki ilkeler iki kısma ayrılır. Birincisi dar veya özel anlamda doğal yasaya ait olan yani sözlerinin ve hükümlerinin bunu zorunlu olarak gerekli kıldığı pratik ilkelerdir. İkincisi sözlerin ikincil veya genel anlamı yani sözlerin anlamı zorunlu olarak ilk ilkelerden çıkmasa da sıradan bir zihin tarafından zorunlu olarak anlașılabilen ilkelerdir.

Scotus doğal yasa ile ilgili Gratian Kararları'nın temel kriterini kabul eder. Gratian Kararlarında buna ilișkin olarak șöyle denilmektedir: "Doğal yasa, rasyonel varlıkların bașlangıcından itibaren yürürlüktedir. Zaman içinde değișmeyen bir sabitlik içindedir.” Duns Scotus'a göre Tanrı'nın her zaman en iyiyi seçmesi Tanrı'nın mutlak bir zorunlulukla hareket etmesini gerektirmez. Tanrı'nın iyi olanı seçmesinde bir zorunluluk söz konusu ise de bu, mantıksal bir zorunluluk değil, Tanrı'nın iyilik ve adalet sıfatlarının gereği olan ahlâkî zorunluluktur. Ona göre Tanrı'nın iyiyi seçmesinin bir bakıma zorunlu olduğu söylenebilir. Fakat bu, imkâna zıt bir zorunluluk değildir. Öyle anlașılıyor ki Scotus, iradeciliği metafiziğin yanı sıra ahlâkî alana da tașımıștır. Buna göre her șeyin ilk nedeni olan tanrısal irade aynı zamanda yaratılmıș bütün zihinlerin de en yüksek yasası olmak durumundadır. İyi ve doğru sadece Tanrı tarafından irade edilmiș olmak bakımından mutlaktır. Buna göre Tanrı insanlara ilettiği ahlâk yasasının yerine bașka bir yasa da gönderebilirdi. Hatta insanları bu yasalardan muaf da tutabilirdi. Yine kötülüğe meyledebileceklerini önceden görmesine rağmen Tanrı'nın, yaratıklarından bazılarına özgürlüklerini kullanma fırsatı bahșetmesi genel nizam ve iyilikle uygunluk içindedir. 


\section{Kaynaklar}

Altuner, İ. (2017). Some Remarks on Averroes' Long Commentary on the Metaphysics Book Alpha Meizon. Entelekya Logico-Metaphysical Review, I (I-2), I-I7.

Augustinus (1999). İtiraflar. (Çev. D. Pamir). İstanbul: Kaknüs Yayınları.

Broadie, A. (1995). The Shadow of Scotus, Edinburgh: T. \& T. Clarc.

Cevizci, A. (1999). Ortaçă̆ Felsefesi Tarihi. Bursa: Asa Kitabevi.

Copleston, F. (1954). A History of Philosophy. New York: Image Books.

Dekker, E. (1998). Scotus Freedom of the Will Revisited. Fobn Duns Scotus: Renewal of Philosophy. (Ed. E. P. Bos). Amsterdam: Rodopi.

Gilson, E. (1978). History of Christian Philolopy in the Middle Ages. New York: Random House.

Gilson, E. (2007). Ortaçağda Felsefe. (Çev. A. Meral). İstanbul: Kabalcı Yayınevi.

Jones, W. T. (2006). Batı Felsefesi Taribi 2: Ortaçağ Düşüncesi. (Çev. H. Hünler). İstanbul: Paradigma Yayınları.

Küçükalay, A. M. (2017). Adil Fiyat: Antik Yunan'dan I6. Yüzyıla. İstanbul: Ötüken Yayınları.

Langston, D. C. (1986). Gods Willing Knowledge. Philadelphia: Pennsylvania State University Press.

Peterson, M. vd. (2006). Akıl ve İnanç: Din Felsefesine Giriş. (Çev. R. Acar). İstanbul: Küre Yayınları.

Quinton, A. (1967). John Duns Scotus. The Encyclopedia of Philosophy. (Ed. P. Edwards). New York: Macmillan.

Sahakian, W. (1990). Felsefe Tarihi. (Çev. A. Yardımlı). İstanbul: İdea Yayınevi.

Scotus, D. (1975). God and Creatures: The 2uodlibetal Questions. (Eds. F. Alluntis \& A. B. Wolter). London: Princeton University Press.

Scotus, D. (1994). Contingency and Freedom (Lectura I 39). (Trans. A. vos Jaczn). Dordrecht: Kluwer Academic Publishers.

Scotus, J. D. (1986). Will and Morality. (Trans. \& ed. A. B. Wolter). Washington: Catholic University of America Press.

Scotus, J. D. (1992). Scotus' Early Oxford Lecture on Individuation. (Trans. \& ed. A. B. Wolter). Santa Barbara: Old Mission.

Thilly, F. (2000). Bir Felsefe Tarihi. (Çev. N. Küçük \& Y. Çevik). İstanbul: İdea 
Yayınevi.

Vorlander, K. (2004). Felsefe Tarihi. (Çev. M. İzzet vd.). İstanbul: Kitabevi.

Vos Jaczn, A. (2000). Scotus on Freedom and the Foundation of Ethics. Leiden: Brill.

Weber, A. (1998). Felsefe Taribi. (Çev. H. V. Eralp). İstanbul: Sosyal Yayınlar.

Wolter, A. B. \& O’Neill, B. (1993). Fohn Duns Scotus: Mary's Architect. New York: Franciscan Institute Publications.

Wikipedia, On Emir. http://tr.wikipedia.org/wiki/On_Emir.

https://w2.vatican.va/content/benedictxvi/en/speeches/2006/september/document s/hf_ben-xvi_spe_200609I2_university-regensburg.html.

Öz: Scotus, Ortaçağ Hristiyan teolojisinin olgunlaşma döneminin önemli şahsiyetlerinden biridir. Scotus'un ele aldığı konuların hemen hepsinin merkezinde, aynı zamanda Ortaçağın en çok tartışma konusu olan iman ve akıl arasındaki ilișkinin tesis edilmesi problemi yer alır. Akıl ve iradenin ilișkisine dair konularda, Scotus'un düșünceleri birçok yönden Augustinuscu-Fransisken geleneğin izlerini taşır. Onun için de Hıristiyanlığın ahlâkî ve dinî içeriği, inancın kuramsal yapılandırmalarından daha anlamlıdır. Scotus, her șeyin zorunlu ve değişmez olduğunu iddiasını, mantık örgüsü güçlü olan bir teoriyle çürütme yoluna gitmiștir. Bu bağlamda "eșzamanlı olumsallık" diye kavramlaștırdığı parlak bir keșifte bulunmuștur. Scotus'un klasik Hristiyan anlayıșını derinden etkileyen bu olumsallık teorisinin esası, fiilî gerçekliğin gerçekte olandan farklı da olabilmesine dayanır. Olumsal gerçeklik teorisi, bir nevi Hıristiyan düşüncenin Antik Yunan düșüncesinden kurtulmasını ifade etmektedir. Olumsallık teorisinin özünü zıtların aynı anda mümkün olması olușturur. Scotus'un sistematik düșüncesi, zorunluluk teolojisi ve olumsallık teolojisi arasındaki ana yöntemsel ayrıma dayalı olarak olușturulur. Zorunlu önermelerin yanı sıra olumsal önermelerin bilgisi de bu doktrine bağlıdır. Gerçekte olumsal önermeler, teolojinin en büyük kısmını olușturur.

Anahtar Kelimeler: Epistemik çaba, bilgi edinme, dıșsalcılık, içselcilik, bilmenin ikici yolu.

${ }^{\left.{ }^{*}\right]}$ Bu makale, yazarın 2008 yllında Ankara Üniversitesi Sosyal Bilimler Enstitüsü'nde savunduğu Duns Scotus'ta İradecilik bașlıklı doktora tezinden üretilmiștir. 